\title{
Residue of Phosphorus Sources Broadcast and Applied on Rows in Forages during Off-Season Crops
}

\author{
Kássia de Paula Barbosa ${ }^{1}$, Carlos Ribeiro Rodrigues ${ }^{1}$, Polyanna Ribeiro Trindade ${ }^{1}$, Raphaell Lopes do Couto ${ }^{1}$, \\ Rosana Souza Silva ${ }^{1}$, Álisson Vanin ${ }^{2}$, Carlos César Evangelista de Menezes'르, Tâmara Pontes Abreu ${ }^{1}$, \\ Lucas Freitas do Nascimento Júnior ${ }^{1}$, Marcos Gustavo Kemmerich Chagas ${ }^{1}$, Tatiana Michlovská Rodrigues ${ }^{1}$ \\ \& Thomas Jefferson Cavalcante ${ }^{1}$ \\ ${ }^{1}$ Goiano Federal Institute, Rio Verde, GO, Brazil \\ 2 Technological Center of the Agroindustrial Cooperative of Rural Producers of Southwest Goiano \\ (CTC-COMIGO), Rio Verde, GO, Brazil \\ Correspondence: Kássia de Paula Barbosa, Street 224, SK block, lot 26, Garden Santa Helena, Santa Helena de \\ Goiás, Goiás, CEP: 75920-000, Brazil. Tel: 55-064-99210-9524. E-mail: kassiadepaulabarbosa@hotmail.com
}

Received: July 16, 2017

doi:10.5539/jas.v9n11p45
Accepted: August 31, $2017 \quad$ Online Published: October 15, 2017

URL: https://doi.org/10.5539/jas.v9n11p45

\begin{abstract}
This study aimed to evaluate the residual effect of phosphorus sources and application techniques in the intercropping of forages during off-season crops. The experimental design was randomized blocks in a $4 \times 2+1$ factorial, being four sources of phosphorus [Bayóvar Reactive Phosphate (BRP), Monoammonium Phosphate (MAP), Simple Superphosphate (SS) and Triple Superphosphate (TS)], two application techniques (broadcasting and on rows) and an additional without phosphorus. The experiment was conducted during the off-season crop. The residual effect of phosphorus fertilization increased the growth and the production of biomass of forage sorghum regarding broadcast SS and TS sources. The lowest P contents in the tissue of plants fertilized with SS and TS may be attributed to the diluting effect, as it achieved the highest production of biomass. The application of TS favored a greater dry matter production in Brachiaria brizantha cv. Piatã. At the depth 0.00-0.05 m, there was a higher P content with the application of BRP. However, the production of biomass was low, a factor that may be related to an overestimation of $\mathrm{P}$ bound to $\mathrm{Ca}$ by the Mehlich-1 extractor. Under cultivation conditions, broadcast SS and TS had a higher residual effect.
\end{abstract}

Keywords: Brachiaria brizantha cv. Piatã forage, Bayóvar Reactive Phosphate, Monoammonium Phosphate, Simple Superphosphate, Sorghum bicolor cv. Chopper forage, Triple Superphosphate

\section{Introduction}

Currently, the planting of soybean crops and sorghum or corn during off-season in the Brazilian Cerrado leaves little time for the producer to perform procedures such as correction and fertilization. Therefore, ways to optimize fertilizer application are sought to improve uptime mainly during harvest, such as the broadcast fertilization of phosphate fertilizers. This practice increases planting speed, reduces loss of time and increases the operating efficiency of machines. However, the use efficiency of different phosphate sources with different application techniques are objects of further studies.

Phosphorus is the primary nutrient limiting plant production in the Cerrado. This is due to high losses by specific adsorption of iron oxy-hydroxides and aluminum occurring at the clay fraction of Cerrado soils, losses by precipitation with $\mathrm{Fe}$ and $\mathrm{Al}$ in the soil solution under acid conditions and $\mathrm{Ca}$ under overliming or alkaline soil conditions (Novais \& Smyth, 1999; Sousa et al., 2016). The efficiency of phosphate fertilizers varies according to soil, application technique, characteristics of phosphatic fertilizers, the culture itself, climate and production syculm (Anghinoni, 2003; Novais \& Smyth, 1999; Prochnow et al., 2003; Sousa \& Lobato, 2003). One way to increase phosphate fertilizer efficiency is to use cover crops that have a high use efficiency of the P applied to the crop. Thus, P remains in the production syculm in an organic form in case off-season plants are used as cover. If cover crops are used for animal feed, part of the residual $\mathrm{P}$ of the crop is exported. However, it thus generates income to replace the $\mathrm{P}$ extracted. The $\mathrm{P}$ kept in organic form reduces the loss of this nutrient in the soil and increases the fertilizer use efficiency. It could potentially reduce doses in cropping syculms during the stabilization phase. The main forages used as cover crops, grown intercropped with off-season crops, maize or 
sorghum, are Brachiaria sp. species. Such plants are highly efficient in absorbing soil P (Lima et al., 2007; Ramos et al., 2009; Ramos et al., 2010; Benício et al., 2011).

Currently, acidulous sources have been sold in larger quantities in the Brazilian market. Acidulous $\mathrm{P}$ sources most commonly used are single superphosphate (SS), triple superphosphate (TS), monoammonium phosphate (MAP) (Fravet et al., 2014; Novais \& Smyth, 1999). Such sources are considered highly reactive and have a high agronomic efficiency (Santos et al., 2008). Lower reactivity phosphates such as rock phosphates have been used as an alternative to soluble sources. Although such phosphates have a less ready availability of phosphorus for plants, they have a lower cost. In soils with a high P drain, the use of reactive phosphate is more convenient since such lower reactivity does not interfere with the diffusion process that guarantees P to plants (Horowitz \& Meurer, 2004; Novais \& Smyth, 1999).

The residual effect of $\mathrm{P}$ sources is directly related to composition, particle size, the solubility of these sources and intrinsic characteristics of the soil. Acidulous $\mathrm{P}$ sources are more soluble than reactive rock phosphate, presenting a lower residual effect. The most soluble sources provide a higher initial productivity gain, while the long residual effect of lower solubility sources may, over time, offset the gap in relation to the first sources, especially in the case of reactive phosphate (Kaminski \& Peruzzo, 1997; Horowitz \& Meurer, 2004; Sousa \& Lobato, 2003). Natural phosphates have typically a lower efficiency, especially during the application year and annual crops, which present a high demand for $\mathrm{P}$ in a short time (Sousa \& Lobato, 2003). In general, MAP is more soluble than TS, and this in turn is more soluble than SS. This is because TS and SS present calcium (Ca) in their composition.

The application techniques of these P sources generated conflicting results. For Alves et al. (1999), the application of $\mathrm{P}$ on rows must be made with caution. Although this practice has the advantage of temporarily reducing the $\mathrm{P}$ sorption by the soil, it decreases the volume of roots, which is a great disadvantage. It can be a factor that prejudices plants during water deficiency periods. Soluble P sources have shown similar results for both forms of application. However, the broadcast application results in higher yields. Although this practice favors greatest losses due to adsorption/precipitation, it encourages further soil volume exploration of the topsoil by roots, an extremely important factor during drought periods, resulting in a higher accumulation of $\mathrm{P}$ per root unit, thus offsetting the formation of not labile P (Klepker \& Anghinoni, 1995; Novais \& Smyth, 1999). On the other hand, broadcast thermophosphates, reactive phosphate (Oliveira Junior, 2008) and Brazilian rock phosphates (Lopes, 1999) present a great efficiency.

There are few relations as for the efficiency of $P$ use and responses to fertilization using different sources of phosphate fertilizers and their application techniques for forage sorghum and piatã grass. It is known that Brachiaria species have a great potential to cycle $\mathrm{P}$ in the soil to the point of increasing the recovery rates of this nutrient in syculms in which this grass is part of the succession of crops mainly due to its greater root growth, tolerance to $\mathrm{Al}$, efficient nutrient absorption and increased ability to use $\mathrm{P}$ under low availability conditions (Rao, 2001; Silva et al., 2003; Sousa \& Lobato, 2003). The low availability of P in Brazilian tropical soils limits the production of forages regardless of the cultivated species (Lima et al., 2007) since phosphorus fertilization increases the production of forages (Benício et al., 2011).

According to Sousa and Lobato (2004), the broadcast application of P may obtain the same efficiency of the application on rows provided the $\mathrm{P}$ contents available in the soil are at adequate levels. Thus, it is expected that the broadcast application obtain the same efficiency as when applied on rows and especially a greater residual effect of the sources with a lower solubility during the off-season crop. The aim of this study was to evaluate the residual effect of different phosphorus sources and their application techniques in forage intercropping during off-season.

\section{Materials and Methods}

The experiment was developed in the field in Rio Verde, Goiás (GO) state, in a Latossolo Vermelho Distrófico (Embrapa, 2013). Its correspondent in the Soil Taxonomy is Oxisol (Embrapa, 2013). The climate is classified as tropical wet (Aw), with a dry winter and a rainy summer (Köppen, 1931).

The experimental design was randomized blocks in a $4 \times 2+1$ factorial design and four sources of phosphorus [Bayóvar Reactive Phosphate, $29 \%$ of total $\mathrm{P}_{2} \mathrm{O}_{5}$ (BRP), Monoammonium Phosphate, $52 \%$ of $\mathrm{P}_{2} \mathrm{O}_{5}$ (MAP), Simple Superphosphate, $18 \%$ of $\mathrm{P}_{2} \mathrm{O}_{5}$ (SS) and Triple Superphosphate, $42 \%$ of $\mathrm{P}_{2} \mathrm{O}_{5}$ (TS)], two forms of application (broadcasting and on rows) and an additional treatment without phosphorus fertilization in four blocks. Before the forage sorghum planting, a soil sampling was conducted at the depths $0.00-0.05,0.05-0.10,0.10-0.20$, $0.20-0.30$ and $0.30-0.40 \mathrm{~m}$ at each plot for chemical characterization before installing the experiment (Table 1). 
The dose of phosphate fertilizer, $150 \mathrm{~kg} \mathrm{ha}^{-1}$ of $\mathrm{P}_{2} \mathrm{O}_{5}$, was defined based on the soil chemical analysis as recommended for the Cerrado (Sousa \& Lobato, 2004).

Table 1. Average values of soil chemical analysis after soybean harvest for phosphorus extracted by Mehlich-1 (P) $\left(\mathrm{mg} \mathrm{dm}{ }^{-3}\right)$, potassium $(\mathrm{K})(\mathrm{mg} \mathrm{dm})$, calcium $(\mathrm{Ca})\left(\mathrm{cmol}_{\mathrm{c}} \mathrm{dm}^{-3}\right)$, magnesium $(\mathrm{Mg})\left(\mathrm{cmol}_{\mathrm{c}} \mathrm{dm}^{-3}\right)$, hydrogen potential $\left(\mathrm{CaCl}_{2}\right)(\mathrm{pH})$, aluminum $(\mathrm{Al})\left(\mathrm{cmol}_{\mathrm{c}} \mathrm{dm}^{-3}\right)$, hydrogen + aluminum $(\mathrm{H}+\mathrm{Al})\left(\mathrm{cmol}_{\mathrm{c}} \mathrm{dm}^{-3}\right)$, cation exchange capacity (CEC), percentage of calcium, magnesium and potassium in the soil CEC (\%) (Ca, Mg and $\mathrm{K}$ ) according to Embrapa (2009), and soil organic matter (SOM) $\left(\mathrm{g} \mathrm{kg}^{-1}\right)$ according to Raij et al. (2001)

\begin{tabular}{|c|c|c|c|c|c|c|c|c|c|c|c|c|}
\hline Treatment & $\begin{array}{l}\text { Application } \\
\text { technique }\end{array}$ & $\begin{array}{l}\text { Depth } \\
\text { (m) }\end{array}$ & $\begin{array}{l}\mathrm{P} \\
\left(\mathrm{mg} \mathrm{dm}^{-3}\right)\end{array}$ & $\begin{array}{l}\mathrm{K} \\
\left.(\mathrm{mg} \mathrm{dm})^{-3}\right)\end{array}$ & $\begin{array}{l}\mathrm{Ca} \\
\left(\mathrm{cmol}_{\mathrm{c}} \mathrm{dm}^{-3}\right)\end{array}$ & $\begin{array}{l}\mathrm{Mg} \\
\left(\mathrm{cmol}_{\mathrm{c}} \mathrm{dm}^{-3}\right)\end{array}$ & $\mathrm{pH}$ & $\begin{array}{l}\mathrm{Al} \\
\left(\mathrm{cmol}_{\mathrm{c}} \mathrm{dm}^{-3}\right)\end{array}$ & $\begin{array}{l}\mathrm{H}+\mathrm{Al} \\
\left(\mathrm{cmol}_{\mathrm{c}} \mathrm{dm}^{-3}\right)\end{array}$ & $\% \mathrm{Ca}$ & $\% \mathrm{Mg}$ & $\% \mathrm{~K}$ \\
\hline BRP & broadcasting & $0.00-0.05$ & 15.21 & 38.50 & 4.44 & 2.51 & 5.45 & 0.16 & 5.45 & 35.52 & 20.08 & 0.79 \\
\hline BRP & broadcasting & $0.05-0.10$ & 5.22 & 39.50 & 4.20 & 2.02 & 5.45 & 0.00 & 5.61 & 35.20 & 16.93 & 0.85 \\
\hline BRP & broadcasting & $0.10-0.20$ & 1.59 & 25.00 & 3.90 & 1.85 & 5.46 & 0.00 & 5.47 & 34.56 & 16.39 & 0.57 \\
\hline BRP & broadcasting & $0.20-0.30$ & 11.66 & 32.00 & 4.45 & 1.79 & 5.43 & 0.00 & 5.08 & 39.03 & 15.70 & 0.72 \\
\hline BRP & broadcasting & $0.30-0.40$ & 0.99 & 16.25 & 3.92 & 0.92 & 5.47 & 0.00 & 4.63 & 41.21 & 9.67 & 0.44 \\
\hline MAP & broadcasting & $0.00-0.05$ & 8.17 & 33.00 & 4.34 & 2.36 & 5.46 & 0.08 & 5.01 & 36.80 & 20.01 & 0.72 \\
\hline MAP & broadcasting & $0.05-0.10$ & 1.67 & 28.50 & 4.42 & 2.29 & 5.49 & 0.11 & 5.38 & 36.34 & 18.83 & 0.60 \\
\hline MAP & broadcasting & $0.10-0.20$ & 2.29 & 22.25 & 4.16 & 2.14 & 5.49 & 0.09 & 4.58 & 38.04 & 19.57 & 0.52 \\
\hline MAP & broadcasting & $0.20-0.30$ & 1.50 & 27.75 & 4.12 & 1.72 & 5.47 & 0.11 & 5.19 & 37.11 & 15.49 & 0.64 \\
\hline MAP & broadcasting & $0.30-0.40$ & 0.41 & 17.50 & 3.61 & 0.88 & 5.48 & 0.07 & 4.20 & 41.33 & 10.07 & 0.51 \\
\hline SS & broadcasting & $0.00-0.05$ & 5.11 & 44.25 & 4.55 & 2.36 & 5.46 & 0.11 & 5.28 & 36.98 & 19.18 & 0.92 \\
\hline SS & broadcasting & $0.05-0.10$ & 3.90 & 43.50 & 4.07 & 1.96 & 5.46 & 0.08 & 4.71 & 37.51 & 18.06 & 1.03 \\
\hline SS & broadcasting & $0.10-0.20$ & 1.62 & 55.75 & 3.90 & 1.93 & 5.45 & 0.08 & 5.28 & 34.66 & 17.15 & 1.27 \\
\hline SS & broadcasting & $0.20-0.30$ & 5.11 & 26.25 & 4.40 & 2.01 & 5.50 & 0.07 & 5.26 & 37.49 & 17.12 & 0.57 \\
\hline SS & broadcasting & $0.30-0.40$ & 0.75 & 22.75 & 3.91 & 1.39 & 5.50 & 0.07 & 4.10 & 41.34 & 14.70 & 0.62 \\
\hline TS & broadcasting & $0.00-0.05$ & 6.62 & 37.50 & 4.30 & 2.22 & 5.43 & 0.03 & 6.26 & 33.40 & 17.24 & 0.75 \\
\hline TS & broadcasting & $0.05-0.10$ & 2.68 & 30.50 & 3.96 & 2.05 & 5.46 & 0.08 & 6.09 & 32.52 & 16.83 & 0.64 \\
\hline TS & broadcasting & $0.10-0.20$ & 0.58 & 21.25 & 3.87 & 1.48 & 5.46 & 0.07 & 6.01 & 33.90 & 12.97 & 0.48 \\
\hline TS & broadcasting & $0.20-0.30$ & 3.30 & 26.75 & 3.88 & 1.81 & 5.45 & 0.05 & 6.07 & 32.80 & 15.30 & 0.58 \\
\hline TS & broadcasting & $0.30-0.40$ & 0.72 & 15.50 & 3.64 & 1.04 & 5.46 & 0.00 & 4.94 & 37.68 & 10.77 & 0.41 \\
\hline BRP & rows & $0.00-0.05$ & 19.15 & 37.25 & 4.41 & 2.42 & 5.45 & 0.00 & 5.00 & 36.98 & 20.29 & 0.80 \\
\hline BRP & rows & $0.05-0.10$ & 3.39 & 32.50 & 4.02 & 2.10 & 5.46 & 0.00 & 5.07 & 35.66 & 18.63 & 0.74 \\
\hline BRP & rows & $0.10-0.20$ & 1.23 & 29.00 & 3.74 & 1.81 & 5.47 & 0.03 & 4.89 & 35.57 & 17.21 & 0.71 \\
\hline BRP & rows & $0.10-0.20$ & 1.23 & 29.00 & 3.74 & 1.81 & 5.47 & 0.03 & 4.89 & 35.57 & 17.21 & 0.71 \\
\hline BRP & rows & $0.20-0.30$ & 24.44 & 28.75 & 4.27 & 2.05 & 5.47 & 0.13 & 4.77 & 38.25 & 18.36 & 0.66 \\
\hline BRP & rows & $0.30-0.40$ & 1.38 & 12.75 & 3.62 & 1.12 & 5.50 & 0.12 & 4.38 & 39.55 & 12.24 & 0.36 \\
\hline MAP & rows & $0.00-0.05$ & 6.43 & 27.25 & 4.00 & 2.12 & 5.47 & 0.11 & 5.35 & 34.66 & 18.37 & 0.61 \\
\hline MAP & rows & $0.05-0.10$ & 5.06 & 23.75 & 4.06 & 2.06 & 5.47 & 0.02 & 5.24 & 35.55 & 18.04 & 0.53 \\
\hline MAP & rows & $0.10-0.20$ & 1.04 & 22.25 & 3.96 & 1.50 & 5.48 & 0.03 & 5.26 & 36.74 & 13.92 & 0.53 \\
\hline MAP & rows & $0.20-0.30$ & 4.18 & 19.50 & 3.97 & 1.81 & 5.48 & 0.10 & 5.39 & 35.38 & 16.13 & 0.45 \\
\hline MAP & rows & $0.30-0.40$ & 0.58 & 11.25 & 3.93 & 1.14 & 5.48 & 0.10 & 4.85 & 39.50 & 11.46 & 0.29 \\
\hline SS & rows & $0.00-0.05$ & 6.88 & 38.75 & 4.26 & 2.15 & 5.45 & 0.00 & 6.13 & 33.70 & 17.01 & 0.79 \\
\hline SS & rows & $0.05-0.10$ & 4.26 & 34.00 & 4.20 & 2.04 & 5.47 & 0.00 & 6.11 & 33.77 & 16.40 & 0.70 \\
\hline SS & rows & $0.10-0.20$ & 1.84 & 37.75 & 4.11 & 1.77 & 5.47 & 0.06 & 5.61 & 35.47 & 15.28 & 0.84 \\
\hline SS & rows & $0.20-0.30$ & 4.02 & 30.00 & 4.17 & 1.90 & 5.47 & 0.06 & 5.93 & 34.53 & 15.73 & 0.64 \\
\hline SS & rows & $0.30-0.40$ & 1.21 & 19.00 & 3.70 & 0.95 & 5.48 & 0.07 & 5.04 & 37.99 & 9.75 & 0.50 \\
\hline $\mathrm{TS}$ & rows & $0.00-0.05$ & 13.74 & 35.25 & 4.23 & 2.26 & 5.46 & 0.04 & 5.66 & 34.56 & 18.46 & 0.74 \\
\hline TS & rows & $0.05-0.10$ & 3.55 & 32.50 & 4.02 & 1.89 & 5.47 & 0.07 & 5.65 & 34.53 & 16.23 & 0.72 \\
\hline TS & rows & $0.10-0.20$ & 1.40 & 22.25 & 3.49 & 1.59 & 5.46 & 0.05 & 6.04 & 31.22 & 14.23 & 0.51 \\
\hline TS & rows & $0.20-0.30$ & 5.20 & 29.75 & 3.98 & 1.69 & 5.46 & 0.07 & 6.01 & 33.85 & 14.38 & 0.65 \\
\hline TS & rows & $0.30-0.40$ & 0.84 & 16.00 & 3.47 & 0.69 & 5.47 & 0.00 & 5.76 & 34.84 & 6.93 & 0.41 \\
\hline Control & & $0.00-0.05$ & 8.47 & 29.00 & 3.90 & 2.22 & 5.46 & 0.00 & 5.95 & 32.11 & 18.28 & 0.61 \\
\hline Control & & $0.05-0.10$ & 5.64 & 23.50 & 3.79 & 1.94 & 5.46 & 0.03 & 5.90 & 32.42 & 16.60 & 0.52 \\
\hline Control & & $0.10-0.20$ & 3.70 & 19.75 & 3.55 & 1.57 & 5.46 & 0.00 & 6.36 & 30.79 & 13.62 & 0.44 \\
\hline Control & & $0.20-0.30$ & 3.31 & 20.75 & 3.63 & 1.51 & 5.47 & 0.00 & 5.23 & 34.83 & 14.49 & 0.51 \\
\hline Control & & $0.30-0.40$ & 3.99 & 10.00 & 3.19 & 0.66 & 5.48 & 0.00 & 4.74 & 37.03 & 7.66 & 0.30 \\
\hline
\end{tabular}


The tested plots consisted of five lines four meters long, spaced half a meter between rows. The forage sorghum cv. Chopper was seeded at $0.03 \mathrm{~m}$ deep. The Piatã grass was sown at $0.06 \mathrm{~m}$ deep mixed with ammonium sulfate at the rate of $20 \mathrm{~kg}$ of seed (Cultural Value $=24 \%)$ for $50 \mathrm{~kg}$ of ammonium sulfate $\left(20 \%\right.$ of N) per hectare. $250 \mathrm{~kg} \mathrm{ha}^{-1}$ of seed mixture, plus ammonium sulfate, were applied.

The experiment was carried out during the off-season from March to July 2015 in succession to a soybean crop, 2014/2015 harvest. The treatments of the sources and the application techniques were applied to the soybean crop in order to later evaluate the residual effect during the off-season.

The biometric variables evaluated for sorghum forage crop were plant height, culm diameter and number of tillers. For these evaluations, ten forage sorghum plants were randomly collected in two main rows of the plot. Culms, leaves and panicles were separated. For piatã grass, the number of tillers was assessed by collecting one linear meter in two central rows of the plot. Subsequently, the leaves and the culm were separated. The fodder was collected after forage harvesting in three random points of the plots. Samples of forages and fodder were washed in distilled water, packed in paper bags and dried in an oven with forced-air circulation at $65-70{ }^{\circ} \mathrm{C}$ until constant weight to estimate yield. After drying, the samples were weighed to determine the dry matter of each part. Subsequently, the samples were ground in a Wiley mill with a $1 \mathrm{~mm}$ sieve and stored in labeled plastic bags. Then, the samples were submitted for chemical analysis of plant tissue to extract and determine the phosphorus content (P) (Embrapa, 2009). Based on P contents in plant tissues and in their biomasses, the accumulation of $\mathrm{P}$ was estimated. The use efficiency of $\mathrm{P}$ (Equation 1) and the agronomic efficiency (Equation 1) were estimated by the formulas adapted from Novais and Smyth (1999).

$$
U E=(\text { Treatment dry matter }) / 150
$$

Where, 150 represents the amount of phosphorus applied to the experimental plots in $\mathrm{kg} \mathrm{ha}^{-1}$.

$$
A E=[(\text { Treatment dry matter-Control dry matter }) / 100] \times 100
$$

After harvesting the forages, the soil was sampled. There were six single samples per plot at each depth evaluated (0.00-0.05, 0.05-0.10, 0.10-0.20, 0.20-0.30 and 0.30-0.40 m). A single sample of each depth evaluated comprised a soil layer between the row and the interrow (Cantarutti et al., 2007). Then, soil samples were chemically analyzed to determine available $P$ with a Mehlich-1 extractor (Embrapa, 2009).

Data were submitted to analysis of variance and means were compared by Tukey test with a significance level of 5\% using the R software (R Development Core Team, 2014). The software Sisvar (Ferreira, 2014) was used for performing orthogonal contrasts among treatments and the additional treatment.

\section{Results}

The $\mathrm{P}$ contents available in the soil obtained a variation only at the depth $0.00-0.05 \mathrm{~m}$ (Figure 1). The application of BRP on rows provided a greater residual effect and availability of $\mathrm{P}$ at the depth $0.00-0.05 \mathrm{~m}$ (Figure 1). In relation to the control, the $\mathrm{P}$ content available at $0.00-0.05 \mathrm{~m}$ was higher only with the application of BRP on rows (Figure 1). Following the BRP applied on rows, the highest values for available phosphorus at the layer 0.00-0.05 $\mathrm{m}$ were obtained with broadcast SS and TS (Figure 1). However, the application of SS and TS by broadcast did not provide available phosphorus values different from those obtained for the control (Figure 1). 


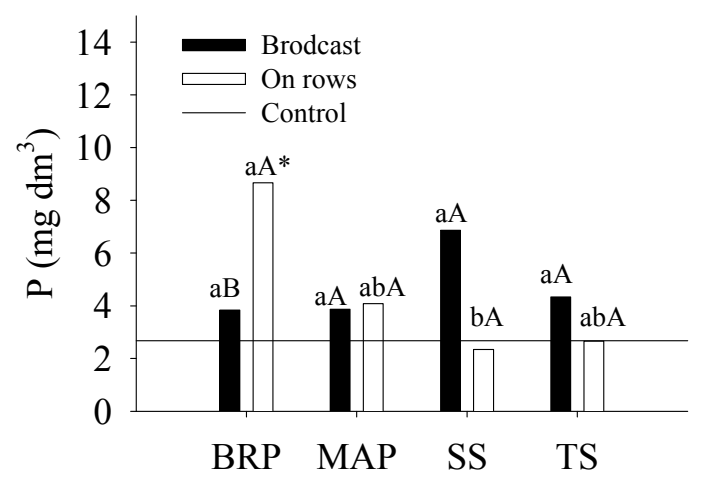

Figure 1. Soil phosphorus content $(\mathrm{P})\left(\mathrm{mg} \mathrm{dm}^{-3}\right)$ by Mehlich-1 extraction after harvesting fodder with different application techniques (broadcast and on rows) and P sources (BRP-Bayóvar Reactive Phosphate,

MAP-Monoammonium Phosphate, SS-Simple Superphosphate, and TS-Triple Superphosphate). A) At the depth 0.00-0.05 m. Rio Verde, GO, 2016

Note. Lowercase letters differ the means of treatments of P sources (Tukey test at 5\%). Uppercase letters differ the treatment means of application techniques (Tukey test at $5 \%$ ). ${ }^{* *},{ }^{*}:$ differ from means of the additional treatment (control) by the Student $t$ test at 1 and 5\% probability, respectively.

For the depths $0.05-0.10,0.10-0.20,0.20-0.30$ and $0.30-0.40 \mathrm{~m}$, there was no change in the availability of $\mathrm{P}$ in the soil profile in relation to the sources and $\mathrm{P}$ application techniques (Table 2). However, the average $\mathrm{P}$ values for the depths $0.05-0.10,0.10-0.20,0.20-0.30$ and $0.30-0.40 \mathrm{~m}$ were $2,72,1.83,1.73$ and $1.49 \mathrm{mg} \mathrm{dm}^{-3}$, respectively.

Table 2. Summary of ANOVA for the variable soil phosphorus content $(\mathrm{P})\left(\mathrm{mg} \mathrm{dm}^{-3}\right)$ extracted by Mehlich-1 at depths $0.00-0.05,0.05-0.10,0.10-0.20,0.20-0.30$ and $0.30-0.40 \mathrm{~m}$ after harvesting forages

\begin{tabular}{lllllll}
\hline & Block & Source $(\mathrm{S})$ & Application $(\mathrm{A})$ & $\mathrm{S}^{*} \mathrm{~A}$ & Additional*Factorial & Error \\
\hline $0.00-0.05$ & $11.45^{\text {ns }}$ & $11.57^{\text {ns }}$ & $0.66^{\text {ns }}$ & $30.85^{*}$ & $12.99^{\text {ns }}$ & 10.11 \\
$0.05-0.10$ & $2.76^{\text {ns }}$ & $1.24^{\text {ns }}$ & $2.17^{\text {ns }}$ & $1.70^{\text {ns }}$ & $0.33^{\text {ns }}$ & 2.30 \\
$0.10-0.20$ & $2.22^{\text {ns }}$ & $1.24^{\text {ns }}$ & $2.17^{\text {ns }}$ & $1.70^{\text {ns }}$ & $0.36^{\text {ns }}$ & 2.35 \\
$0.20-0.30$ & $3.09^{\text {ns }}$ & $1.24^{\text {ns }}$ & $2.17^{\text {ns }}$ & $1.70^{\text {ns }}$ & $0.01^{\text {ns }}$ & 2.34 \\
$0.30-0.40$ & $2.63^{\text {ns }}$ & $1.24^{\text {ns }}$ & $2.17^{\text {ns }}$ & $1.70^{\text {ns }}$ & $0.81^{\text {ns }}$ & 2.32 \\
\hline
\end{tabular}

Note. $^{* *},{ }^{*}$ and ${ }^{\text {ns }}$ : Significant at 1 and $5 \%$ and not significant, respectively, by $\mathrm{F}$ test.

The height (He) (m), the number of tillers (NT), phosphorus accumulation in the panicle (Apan) $\left(\mathrm{kg} \mathrm{ha}^{-1}\right)$ and the total phosphorus accumulation (leaf + culm + panicle) (Atotal) $\left(\mathrm{kg} \mathrm{h}^{-1}\right)$ of forage sorghum plants did not change according to $\mathrm{P}$ sources and application techniques. However, the height of plants fertilized with phosphorus (P) was higher than the control (Figure 2A). Regardless of application technique, the fertilization with triple superphosphate (TS) promoted an increase in culm diameter (CD) (m) (Figure 2B) higher than the Control. 
A

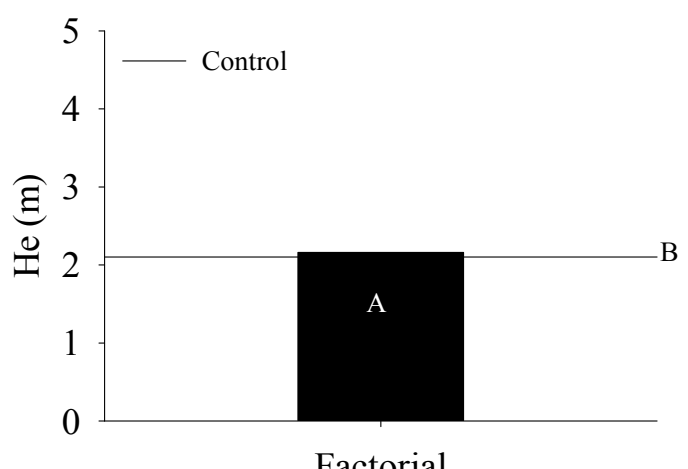

B

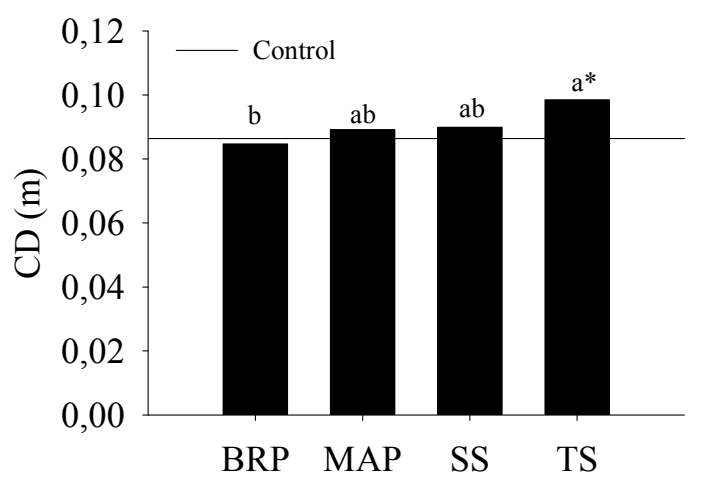

Figure 2. Growth of forage forage sorghum with different application techniques (broadcast and planting on rows) and P sources (BRP-Bayóvar Reactive Phosphate, MAP-monoammonium phosphate, SS-Simple Superphosphate, and ST-Triple Superphosphate). A) Plant height of forage sorghum (He) (m), and B) Culm diameter of forage sorghum (CD) (m). Rio Verde, GO, 2016

Note. Lowercase letters differ the means of treatments of P sources (Tukey test at 5\%). Uppercase letters differ the treatment means of application techniques (Tukey test at 5\%). ${ }^{* *},{ }^{*}:$ differ from means of the additional treatment (control) by the Student $t$ test at 1 and $5 \%$ probability, respectively.

Forage sorghum plants fertilized with broadcast SS and TS showed a greater panicle dry matter (PDM) and total dry matter (leaf + culm + panicle) $(\mathrm{TDM})\left(\mathrm{kg} \mathrm{ha}^{-1}\right)$ (Figures 3A and 3B, respectively). The treatments mentioned above differ from the Control regarding these variables (Figures $3 \mathrm{~A}$ and $3 \mathrm{~B}$, respectively). Regarding the culm-leaf ratio $(\mathrm{L} / \mathrm{C})$, the application on rows of $\mathrm{P}$ sources resulted in a greater value than the broadcast application. $\mathrm{BRP}$ had a higher $\mathrm{L} / \mathrm{C}$ ratio (Figure $3 \mathrm{C}$ ). All treatments differed from the Control regarding this variable (Figure $3 \mathrm{C})$. 
A

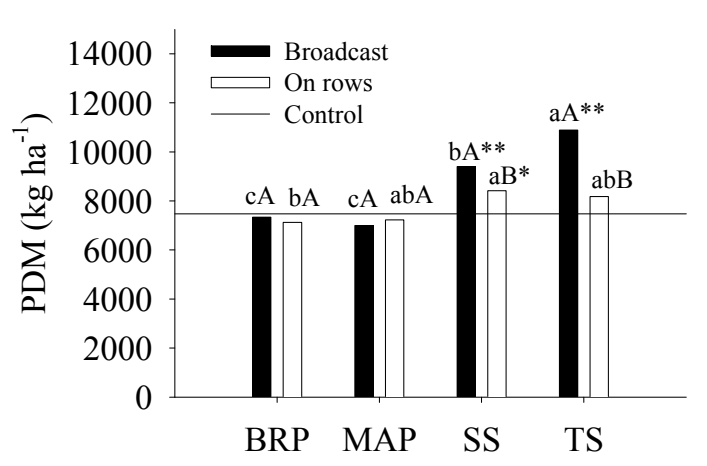

B

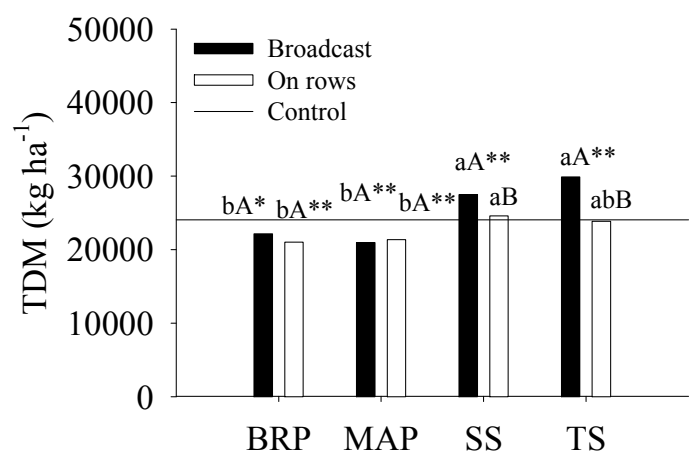

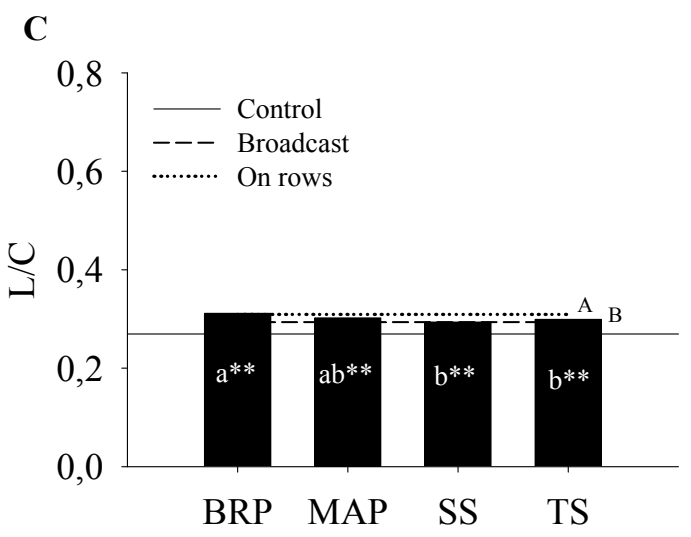

Figure 3. Production of forage sorghum with different application techniques (broadcast and planting in rows) and P sources (BRP-Bayóvar Reactive Phosphate, MAP-Monoammonium phosphate, SS-Simple Superphosphate, and ST-Triple Superphosphate). A) panicle dry matter (PDM) $\left(\mathrm{kg} \mathrm{ha}^{-1}\right)$, B) total dry matter (culm + leaves + panicle)

(TDM) $\left(\mathrm{kg} \mathrm{ha}^{-1}\right)$, and C) leaf-culm ratio (L/C) of forage sorghum plants. Rio Verde, GO, 2016

Note. Lowercase letters differ the means of treatments of P sources (Tukey test at 5\%). Uppercase letters differ the treatment means of application techniques (Tukey test at 5\%). ${ }^{* *},{ }^{*}:$ differ from means of the additional treatment (control) by the Student $t$ test at 1 and $5 \%$ probability, respectively.

The number of tillers and the leaf-culm ratio of piatã grass did not vary among treatments. Only total dry matter (TDM) $\left(\mathrm{kg} \mathrm{ha}^{-1}\right)$ and total accumulation of phosphorus (Atotal) $\left(\mathrm{kg} \mathrm{ha}^{-1}\right)$ varied according to treatments. The TDM of piatã grass was higher when TS was applied independently from the application technique. A TDM of $1,801.87 \mathrm{~kg} \mathrm{ha}^{-1}$ was obtained and this was higher than the control treatment (Figure 4A). The application of broadcast BRP provided a greater Atotal for piatã grass, and this value was higher than the control (Figure 4B). This shows that piatã grass was more efficient in absorbing P from a low reactivity source, such as BRP, than forage sorghum plants. 
A

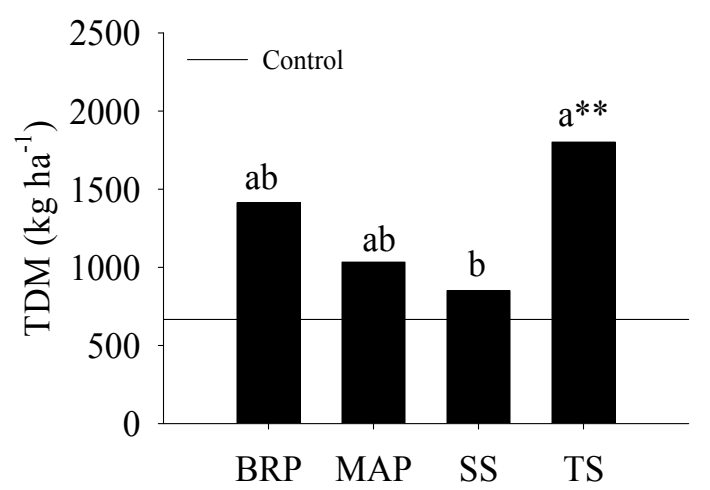

B

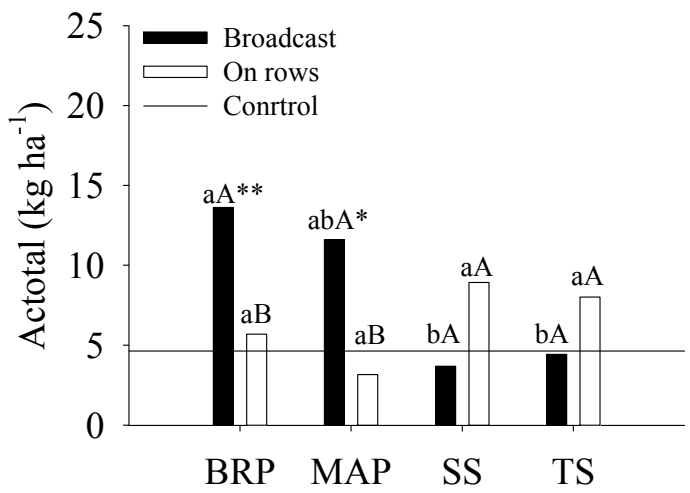

Figure 4. Production and accumulation of $\mathrm{P}$ in piatã grass with different application techniques (broadcast and planting in rows) and P sources (BRP-Bayóvar Reactive Phosphate, MAP-Monoammonium phosphate, SS-Simple Superphosphate, and ST-Triple Superphosphate). A) total dry matter of piatã grass (TDM) $\left(\mathrm{kg} \mathrm{ha}^{-1}\right)$ and B) total accumulation of phosphorus (leaf + culm) of piatã grass (Atotal) $\left(\mathrm{kg} \mathrm{ha}^{-1}\right)$. Rio Verde, GO, 2016

Note. Lowercase letters differ the means of treatments of P sources (Tukey test at $5 \%$ ). Uppercase letters differ the treatment means of application techniques (Tukey test at 5\%). ${ }^{* *},{ }^{*}:$ differ from means of the additional treatment (control) by the Student $t$ test at 1 and 5\% probability, respectively.

The variables total biomass (sorghum + grass) $(\mathrm{TB})\left(\mathrm{kg} \mathrm{ha}^{-1}\right)$, production of straw (Pstraw) $\left(\mathrm{kg} \mathrm{ha}^{-1}\right)$ and phosphorus accumulation in the straw after harvesting forages (Astraw) $\left(\mathrm{kg} \mathrm{ha}^{-1}\right)$ did not vary in function of sources and forms of $\mathrm{P}$ or an interaction between them. The mean value for total biomass was $11.15 \mathrm{tha}^{-1}$ and the value for the production of straw was $10.80 \mathrm{tha}^{-1}$.

The efficiency of $\mathrm{P}$ use by forage sorghum (EUS) $\left(\mathrm{kg} \mathrm{kg}^{-1}\right.$ of $\left.\mathrm{P}_{2} \mathrm{O}_{5} 5\right)$ and the agronomic effectiveness of $\mathrm{P}$ sources for the forage sorghum crop (AES) (\%) did not present a significant variation (Figures 5A and 5B). However, the highest values were obtained when SS and TS were applied, confirming the increased production of panicles of forage sorghum when these fertilizers were applied (Figures 5A and 5B). Such results are explained by the greater availability of $\mathrm{P}$ at the layer $0.00-0.05 \mathrm{~m}$ during the off-season crop when SS and TS were applied. The efficiency of $\mathrm{P}$ use by Brachiaria (EUB) $\left(\mathrm{kg} \mathrm{kg}^{-1}\right.$ of $\mathrm{P}_{2} \mathrm{O}_{5}$ ) (Figure 5C) and the agronomic effectiveness of $\mathrm{P}$ sources for Brachiaria (AEB) (\%) (Figure 5D) were higher when TS was applied. Independently from the application technique, this treatment was significantly higher than the control. 
A

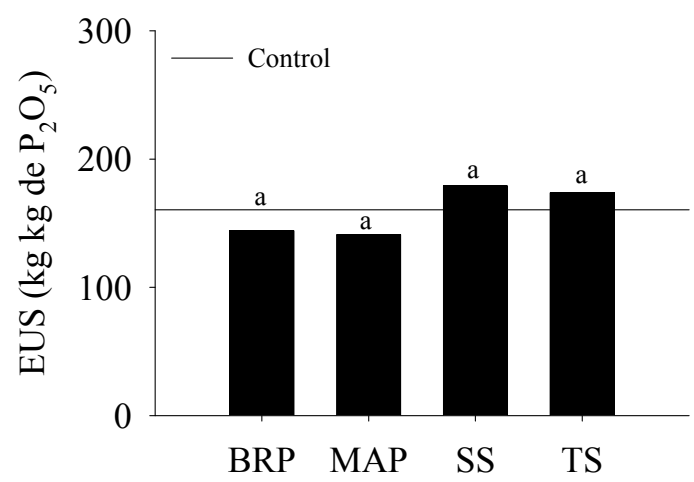

C

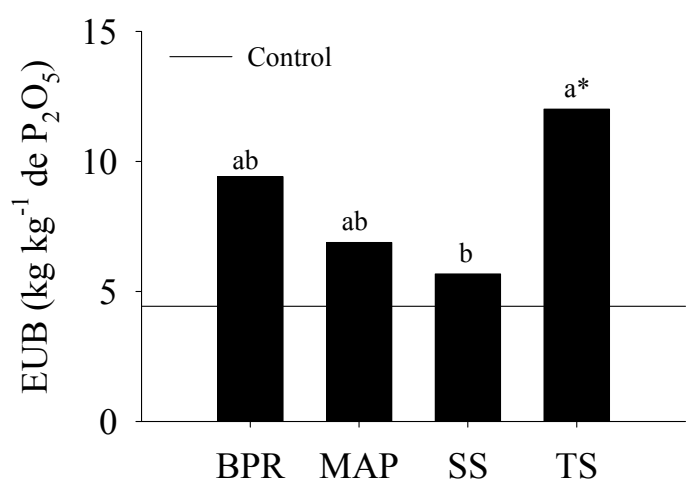

B

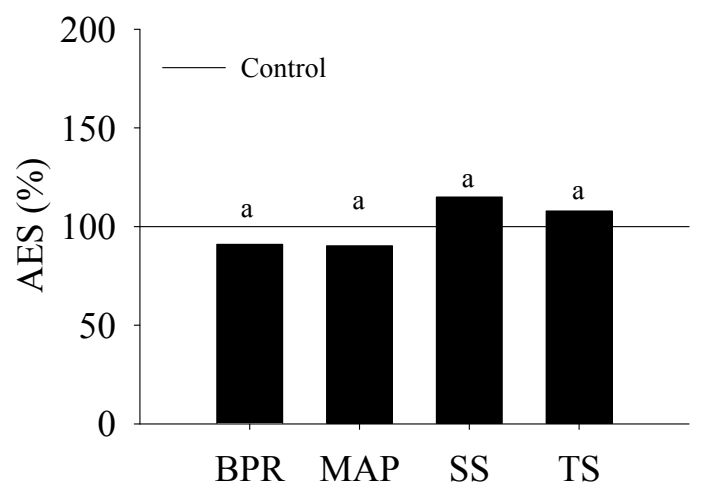

D

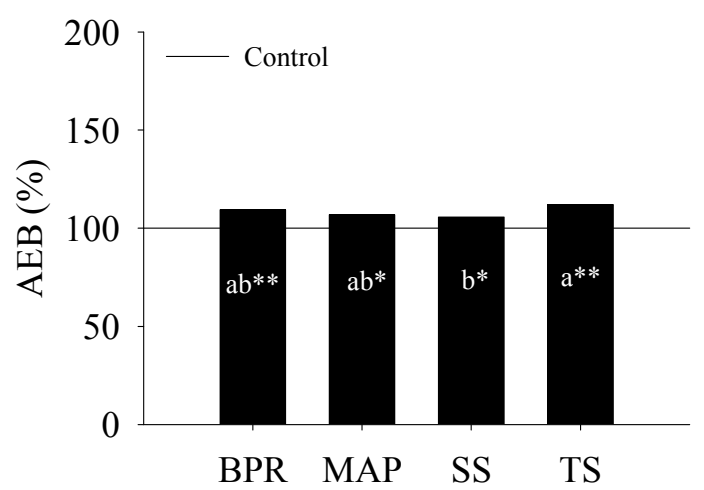

Figure 5. Efficiency of $\mathrm{P}$ use $\left(\mathrm{kg} \mathrm{kg}^{-1}\right.$ of $\left.\mathrm{P}_{2} \mathrm{O}_{5}\right)$ and agronomic efficiency of $\mathrm{P}$ sources (\%) with different application techniques (broadcast and planting in rows) and P sources (BRP-Bayóvar Reactive Phosphate,

MAP-Monoammonium phosphate, SS-Simple Superphosphate, and ST-Triple Superphosphate). A) efficiency of use of $\mathrm{P}$ in forage sorghum (EUS) $\left(\mathrm{kg} \mathrm{kg}^{-1}\right.$ of $\left.\mathrm{P}_{2} \mathrm{O}_{5}\right)$; B) agronomic efficiency of forage sorghum (AES) (\%); C) efficiency of use of $\mathrm{P}$ in Brachiaria (EUB) $\left(\mathrm{kg} \mathrm{kg}^{-1}\right.$ of $\left.\mathrm{P}_{2} \mathrm{O}_{5}\right)$ and D) agronomic efficiency of Brachiaria (AEB) (\%). Rio Verde, GO, 2016

Note. Lowercase letters differ the means of treatments of P sources (Tukey test at 5\%). Uppercase letters differ the treatment means of application techniques (Tukey test at 5\%). ${ }^{* *},:$ differ from means of the additional treatment (control) by the Student $t$ test at 1 and $5 \%$ probability, respectively.

\section{Discussion}

It was observed that with the increase of the depth there was decrease in the P content in the soil independent of the treatments. Similar results were found by Barbosa et al. (2015). In BRP treatments, greater values for available phosphorus in the soil were obtained (Figure 1). However, the production of biomass of plants fertilized with BRP was low. This contradiction between the values of soil available phosphorus and biomass for plants fertilized with BRP may be attributed to the overestimation of $\mathrm{P}$ bound to Ca by the Mehlich-1 extractor. This form of $\mathrm{P}$ is not available for plants (Gatiboni et al., 2003). The extraction of P occurs by acid dissolution of low-energy phosphate compounds. It is higher for calcium phosphate, followed by aluminum bound to phosphates and iron. A side effect of the ion exchange may occur on phosphate sulfate ion adsorption sites (Santos et al., 2008). The Mehlich-1 extractor overestimates the available P mainly from BRP since it also extracts soil unreacted P. This source of P has a residual effect even greater than acidulous sources, as it slowly provides the available $\mathrm{P}$, hence the importance of long term studies. Acidulous P sources are more soluble than BRP. Thus, they provide readily available $\mathrm{P}$ to plants. Another factor that contributes to the solubility of these sources is the Ca drain factor. Thus, the soil with a greater drain factor provides an enhanced release of $\mathrm{P}$ that can be absorbed by plants. This justifies the high production of fodder.

Before planting the forages, the Ca content in the soil ranged from 3.7 to $4.55 \mathrm{cmol}_{\mathrm{c}} \mathrm{dm}^{-3}$, which resulted in up to $35 \%$ of $\mathrm{Ca}$ in CEC (Table 1). That is, the soil had high levels of $\mathrm{Ca}$, which reduced the $\mathrm{Ca}$ drain of the soil. This explains the lower efficiency of SS and TS during harvest (Couto et al., 2015) and the higher residual effect on the 
availability of P during off-season (Figure 1). Another factor that may have reduced the solubilization of SS and TS during harvest was water stress and the lack of rain for up to 20 days. However, during off-season, there was a good rainfall distribution, which helped in a better dissolution of the fertilizer into the soil. $\mathrm{P}$ is a little mobile element in the soil. Its transport to roots is made through mass flow and mainly by diffusion, which depends on humidity and radicial surface (Gahoonia et al., 1994). Then, under water stress, a limitation of P may occur even though this nutrient is supplied to the soil (Munson \& Nelson, 1973). However, the application technique of these soluble P sources may also influence the P uptake by plants. Studies show that, when broadcast, there is an increased production due to the favoring of a greater exploitation of soil volume at topsoil by roots. This is an important factor during drought periods, resulting in a higher accumulation of $\mathrm{P}$ per root unit, contributing to a further development of plants (Klepker \& Anghinoni, 1995; Novais \& Smyth, 1999).

The non-variation of $\mathrm{P}$ in Table 2 contents at layers below $0.05 \mathrm{~m}$ reflects the low mobility of this nutrient inside the soil (Santos et al., 2008; Klein \& Agne, 2012). P deficiency decreases the development and the establishment of the culture, demonstrating the importance of phosphorus fertilization. Similar to that observed for soybeans (Lucena et al., 2000), in this study the application of TS increased the culm diameter of forage sorghum plants (Figure 2B). The increase in culm diameter decreases losses by tipping, maintaining forage quality.

A plant subjected to optimal nutrition conditions, especially of phosphorus and calcium, has a more developed root syculm as a result of a higher production of assimilates (Guedes et al., 2009). Thus, the presence of calcium in the composition of SS and TS and its availability during the off-season crop contributed to obtain an increased production of PDM and TDM (Figures 3A and 3B). This higher leaf-culm ratio can be justified by the lower development of culms of forage sorghum plants fertilized with BRP, which presented a greater leaf development (Figure 3C). The leaf-culm ratio is very relevant in studies of forage grasses since the higher number of leaves over culms indicates a better adaptation of plants to grazing and cuttings (Silva et al., 2013).

Passos et al. (1997) evaluated the effects of phosphorus sources (magnesium thermophosphate and triple superphosphate) on two potted grasses (Brachiaria and Andropogon) and found that phosphorus sources did not differ regarding the number of tillers per Brachiaria pot, imilar result was found in the present study. This effect evidences the high potential of this forage as a cover for cycling $\mathrm{P}$ in the soil, keeping it into the organic matter and reducing losses due to adsorption (Figure 4B). Dias et al. (2015) evaluating the production of Piatã grass submitted to different sources of phosphorus report that the Piatã grass was responsive to phosphate fertilization when compared to the control. Ramos et al. (2009) also observed that plants from the genus Brachiaria were more efficient in absorbing $\mathrm{P}$ from low solubility sources compared with forage sorghum.

According to Ieiri et al. (2010), in a study of sources (Triple superphosphate, Magnesium thermophosphate and Gafsa Hyperphosphate), doses and phosphorus application techniques on pasture, TS promotes a greater dry matter increase compared to the other sources used due to high water solubility, providing greater amounts of phosphorus to the plant in its early days. Costa et al. (2008), who tested different sources of phosphorus in Marandu grass, verified that the dry matter production and the total accumulation of $\mathrm{P}$ were more efficient in treatments with high soluble sources (such as TS), rock reactive phosphate and a mix between them. It is noteworthy that the P content in the TDM does not always have a direct relation with the production of TDM. Therefore, plants that have a higher production of TDM may have lower levels of P and consequently less accumulation of $P$ in their tissue as a result of the dilution effect (Faquin et al., 1997).

Because it has a higher solubility than the other sources of P, the MAP released phosphorus and nitrogen for soybeans, which may have favored a grain yield and dry matter at harvest higher than at the off-season (Couto et al., 2015) since the SS and TS did not show the same results. This effect that may be related to their low solubility, water stress conditions and the $\mathrm{Ca}$ drain factor, which was high during the soybean crop. During off-season, there was a better rainfall distribution during the experimental period. It may have favored the availability of phosphorus adsorbed by the crop due to high humidity and temperatures. Barrow (1974) evaluated the effects of time, temperature and water content in the soil on the decrease of $\mathrm{P}$ for plant development and noted that the relations between adsorption and precipitation are accelerated with the increase in the temperature and soil moisture.

Generally, the residual effect of phosphorus fertilization increased the growth and biomass production of forage sorghum, mainly regarding acidulous phosphorus sources broadcast (SS and TS). This high production can be justified by the high availability of $P$ in the soil of these treatments (Figure 1). The lowest accumulation of $P$ contents in the tissue of plants fertilized with SS and TS may be attributed to the diluting effect of this nutrient, as it achieved the highest biomass production. The high solubility of these phosphate fertilizers is responsible for the release of phosphate ions into the soil more quickly, resulting in immediate gains in crop productivity in 
relation to BRPs (Scholefield et al., 1999; Ramos et al., 2009). However, over many years, the effect of BRPs may be similar (Resende et al., 2006) or even higher (Scholefield et al., 1999) than soluble phosphates due to their higher residual effect. Rodrigues et al. (2009) state that lower solubility sources are an alternative that allows residual effects and a better use of the $\mathrm{P}$ source due to their slower release into the soil solution, reducing fixation and increasing nutrient use by culture succession.

\section{Conclusions}

By analyzing the results and the conditions of this experiment:

The application of TS broadcast and on rows promoted an increase in the dry matter production of piatã grass. Forage sorghum shading decreased the responses of piatã grass to treatments.

Piatã grass was also more efficient in absorbing P from BRP.

The phosphorus sources SS and TS, both broadcast and applied on rows, showed a greater residual effect and a higher dry matter production and growth of forage sorghum.

\section{References}

Alves, V. M. C., Magalhães, J. V., Vasconcelos, C. A., Novais, R. F., Bahia Filho, A. F. C., França, G. E., ... França, C. C. M. (1999). Acúmulo de nitrogênio e de fósforo em plantas de milho afetadas pelo suprimento parcial de fósforo às raízes. Revista Brasileira de Ciência do Solo, 23, 299-305. https://doi.org/10.1590/ S0100-06831999000200014

Anghinoni, I. (2003). Fatores que interferem na eficiência da adubação fosfatada [CD-ROM]. Simpósio sobre fósforo na agricultura Brasileira, 1, Piracicaba-SP. Anais... Piracicaba: Potafos/Anda.

Barbosa, N. C., Arruda, E. M., Brod, E., \& Pereira, H. S. (2015). Distribuição vertical do fósforo no solo em função dos modos de aplicação. Bioscience Journal, 31, 87-95. https://doi.org/10.14393/BJ-v31n1a 2015-18196

Barrow, N. J. (1974). The slow reactions between soil and anions. 1. Effects of time, temperature, and water content of soil on the decrease in effectiveness of phosphate for plant growth. Soil Science, 118, 380-386. https://doi.org/10.1097/00010694-197412000-00006

Benício, L. P. F., Oliveira, V. A., Silva, L. L., Rosanova, C., \& Oliveira, S. L. (2011). Produção de Panicum maximum consorciado com sorgo sob diferentes fontes de fósforo. Tecnologia \& Ciência Agropecuária, 5, $55-60$.

Cantarutti, R. B., Barros, N. F., Martinez, H. E. P., \& Novais, R. F. (2007). Avaliação da fertilidade do solo e recomendação de fertilizantes. In R. F. Novais, V. V. H. Alvaez, N. F. Barroz, R. B. Cantarutti, \& J. C. L. Neves (Eds.), Fertilidade do Solo (pp. 769-850). Viçosa-MG: SBCS.

Costa, S. E. V. G. A., Furtini Neto, A. E., Resende, A. V., Silva, T. O., \& Silva, T. R. (2008). Crescimento e nutrição da Braquiária em função de fontes de fósforo. Ciência e Agrotecnologia, 32, 1419-1427. https://doi.org/10.1590/S1413-70542008000500010

Couto, R. L., Barbosa, K. P., Rodrigues, C. R., Chagas, M. G. K., Menezes, C. C. E., \& Vanin, A. (2015). Fontes e formas de aplicação de P em Latossolo Vermelho do Sudoeste Goiano. XXXV Congresso Brasileiro de Ciência do Solo. Anais... Natal: SBCS.

Dias, D. G., Pegoraro, R. F., Alves, D. D., Porto, E. M. V., Santos Neto, J. A., \& Aspiazú, I. (2015). Produção do capim Piatã submetido a diferentes fontes de fósforo. Revista Brasileira de Engenharia Agrícola e Ambiental, 19, 330-335. https://doi.org/10.1590/1807-1929/agriambi.v19n4p330-335

Embrapa. (2009). Manual de análises químicas de solos, plantas e fertilizantes (2nd ed., p. 627). Brasília: Embrapa Informação Tecnológica.

Embrapa. (2013). Sistema brasileiro de classificação de solos (3rd ed., p. 353). Brasília: Embrapa Solos.

Faquin, V., Rossi, C., Curi, N., \& Evangelista, A. R. (1997). Nutrição mineral em fósforo, cálcio e magnésio do Braquiarão em amostras de Latossolo dos Campos das Vertentes sob influência de calagem e fontes de fósforo. Revista Brasileira de Zootecnia, 26, 1074-1082.

Ferreira, D. F. (2014). Sisvar: A Guide for its Bootstrap procedures in multiple comparisons. Ciência e Agrotecnologia, 38, 109-112. https://doi.org/10.1590/S1413-70542014000200001

Fravet, P. R. F., Gervasio, G. R., Nogueira, G., \& Zineli, V. (2014). Avaliação visual de nutrição de plantas (ISAH Circular Técnica, 8, p. 6). Araxá: Instituto de Ciências da Saúde, Agrárias e Humanas (ISAH). 
Gahoonia, T. S., Raza, S., \& Nielsen, N. E. (1994). Phosphorus depletion in the rhizosfere as influenced by soil moisture. Plant and Soil, 159, 213-218. https://doi.org/10.1007/BF00009283

Gatiboni, L. C., Kaminskia, L., Rheinheimera, D. S., \& Brunettoa, G. (2003). Superphosphate and rock phosphates as Phosphorus sources for grass-clover pasture on a limed acid soil in Southern Brazil. Communications in Soil Science and Plant Analysis, 34, 2503-2514. https://doi.org/10.1081/CSS120024782

Guedes, E. M. S., Fernandes, A. R., Lima, E. V., Gama, M. A. P., \& Silva, A. L. P. (2009). Fosfato natural de Arad e calagem e o crescimento de Brachiaria brizanta em latossolo amarelo sob pastagem degradada na Amazônia. Revista de Ciências Agrárias, 52, 117-129.

Horowitz, N., \& Murere, E. J. (2004). Eficiência agronômica de fosfatos naturais. In T. Yamada \& S. R. S. Abdalla (Eds.), Fósforo na agricultura brasileira (pp. 665-682). Piracicaba: Potafos.

Ieiri, A. Y., Lana, R. M. Q., Korndorfer, G. H., \& Pereira, H. S. (2010). Fontes, doses e modos de aplicação de fósforo na recuperação de pastagem com brachiaria. Ciência e Agrotecnologia, 34, 1154-1160. https://doi.org/10.1590/S1413-70542010000500011

Kaminski, J., \& Peruzzo, G. (1997). Eficácia de fosfatos naturais reativos em sistemas de cultivo (Boletim Técnico, 3, p. 31). Santa Maria: SBCS.

Klein, C., \& Agne, S. A. A. (2012). Fósforo: De nutriente a poluente! Revista Eletrônica em Gestão, Educação e Tecnologia Ambiental, 8, 1713-1721. https://doi.org/10.5902/223611706430

Klepker, D., \& Anghinoni, I. (1995). Características físicas e químicas do solo afetadas por métodos de preparo e modos de adubação. Revista Brasileira de Ciência do Solo, 19, 395-401.

Köppen, W. (1931). Grundriss der Klimakunde: Outline of climate Science (p. 388). Berlin: Walter de Gruyter.

Lima, S. O., Fidelis, R. R., \& Costa, S. J. (2007). Avaliação de fontes e doses de fósforo no estabelecimento de brachiaria brizanta cv. Marandú no sul do Tocantins. Pesquisa Agropecuária Tropical, 37, 100-105.

Lopes, A. S. (1999). Fosfatos naturais. In A. C. Ribeiro, P. T. G. Guimarães, \& V. H. A. Venegas (Eds.), Recomendações para o uso de corretivos e fertilizantes em Minas Gerais: $5^{\circ}$ aproximação (pp. 65-66). Viçosa: CFSEMG.

Lucena, L. F. C., Oliveira, F. A., Silva, I. F., \& Andrade, A. P. (2000). Respostas do milho a diferentes níveis de nitrogênio e fósforo aplicados ao solo. Revista Brasileira de Engenharia Agrícola e Ambiental, 4, 334-337. https://doi.org/10.1590/S1415-43662000000300005

Munson, R. D., \& Nelson, W. L. (1973). Principles and practices in plant analysis. In L. M. Walsh \& I. D. Beaton (Eds.), Soil testing and plant analysis (pp. 223-248). Madison: Soil Science Society of America.

Novais, R. F., \& Smyth, T. J. (1999). Fósforo em solo e planta em condições tropicais (p. 399). Viçosa: UFV.

Oliveira Junior, A., Prochnow, L. I., \& Klepker, D. (2008). Eficiência agronômica de fosfato natural reativo na cultura da soja. Pesquisa Agropecuária Brasileira, 43, 623-631. https://doi.org/10.1590/S0100-204X20080 00500010

Passos, R. R., Faquin, V., Curi, N., Evangelista, A. R., \& Villa, M. R. (1997). Fontes de fósforo, calcário e gesso na produção de matéria seca e perfilhamento de duas gramíneas forrageiras em amostras de um latossolo ácido. Revista Brasileira de Zootecnia, 26, 227-233.

Prochnow, L. I., Alcarde, J. C., \& Chien, S. H. (2003). Eficiência agronômica dos fosfatos totalmente acidulados [CD-ROM] (p. 67). Simpósio sobre fósforo na agricultura brasileira. Anais... Piracicaba: Potafos/Anda.

R Develoment Core Team. (2014). R: A language and environment for statistical computing. Retrieved from http://www.r-project.org

Ramos, S. J., Faquin, V., Rodrigues, C. R., \& Silva, C. A. (2010). Efeito residual das aplicações de fontes de fósforo em gramíneas forrageiras sobre o cultivo sucessivo da soja em vasos. Bragantia, 69, 149-155. https://doi.org/10.1590/S0006-87052010000100019

Ramos, S. J., Faquin, V., Rodrigues, C. R., Silva, C. A., \& Boldrin, P. F. (2009). Biomass production and phosphorus use of forage grasses fertilized with two phosphorus sources. Revista Brasileira de Ciência do Solo, 33, 335-343. http://dx.doi.org/10.1590/S0100-06832009000200011

Rao, I. M. (2001). Adapting tropical forages to low-fertility soils (pp. 247-254). XIX International Grassland Congress. Annals... Piracicaba: Brazilian Society of Animal Husbandry. 
Resende, A. V., Furtini Neto, A. E., Alves, V. M. C., Muniz, J. A., Curi, N., Faquin, V., ... Carneiro, L. F. (2006) Fontes e modos de aplicação de fósforo para o milho em solo cultivado da região do cerrado. Revista Brasileira de Ciência do Solo, 30, 453-466. https://doi.org/10.1590/S0100-06832006000300007

Rodrigues, C. R., Faquin, V., Ávila, F. W., Rodrigues, T. M., Baliza, D. P., \& Oliveira, E. A. B. (2009). Crescimento e acúmulo de fósforo pela soja cultivada em sucessão a diferentes gramíneas forrageiras adubadas com super fosfato triplo e fosfato reativo de Arad. Ciência e Agrotecnologia, 33, 1486-1494. https://doi.org/10.1590/S1413-70542009000600005

Santos, D. R., Gatiboni, L. C., \& Kaminski, J. (2008). Fatores que afetam a disponibilidade do fósforo e o manejo da adubação fosfatada em solos sob sistema plantio direto. Ciência Rural, 38, 576-586. https://doi.org/10.1590/S0103-84782008000200049

Scholefield, D., Shoeldrick, R. D., Martyn, T. M., \& Lavender, R. H. (1999). A comparison of triple superphosphate and Gafsa ground rock phosphate fertilizers as P-sources for grass-clover swards on a poorly-drained acid clay soil. Nutrient Cycling in Agroecosystems, 53, 147-155. https://doi.org/10.1023/ A:1009750623318

Silva, D. R. G, Costa, K. A. P, Faquin, V., Oliveira, I. P., \& Bernardes, T. F. (2013). Doses e fontes de nitrogênio na recuperação das características estruturais e produtivas do capim-marandu. Revista Ciência Agronômica, 44, 184-191. https://doi.org/10.1590/S1806-66902013000100023

Silva, M. A., Nóbrega, J. C. A., Curi, N., Siqueira, J. O., Sá, J. J. G., Marques, M., \& Motta, P. E. F. (2003). Frações de fósforo em Latossolos. Pesquisa Agropecuária Brasileira, 38, 1197-1207. https://doi.org/ 10.1590/S0100-204X2003001000009

Sousa, D. M. G., \& Lobato, E. (2003). Adubação fosfatada em solos da região do Cerrado (Informações Agronômicas, 102, p. 16). Piracicaba: Potafos.

Sousa, D. M. G., \& Lobato, E. (2004). Cerrado: Correção do solo e adubação (2nd ed., p. 416). Planaltina: Embrapa Cerrados.

Sousa, D. M. G., Nunes, R. S., Rein, T. A., \& Santos Junior, J. D. G. (2016). Manejo do fósforo na região do Cerrado. In R. A. Flores \& P. P. Cunha (Eds.), Práticas de manejo do solo para adequada nutrição de plantas no Cerrado (pp. 291-357). Goiânia: UFG.

\section{Copyrights}

Copyright for this article is retained by the author(s), with first publication rights granted to the journal.

This is an open-access article distributed under the terms and conditions of the Creative Commons Attribution license (http://creativecommons.org/licenses/by/4.0/). 